\title{
Desires under Reform: Contemporary Reconfigurations of Family, Marriage, Love and Gendering in a transnational South Indian Matrilineal Muslim
} community

Caroline Osella, Anthropology, SOAS, London, UK. Co6@soas.ac.uk

Keywords: South Asia, Muslim, Marriage, Kinship, Gender, Migration.

\begin{abstract}
I trace here some connections between contemporary reconfigurations of gendering, family and marriage in a matrilineal Muslim south Indian community (Kerala Koyas). I argue that shifts from joint matrifocal households to small neo-patriarchal households are underscored by market reforms, migration processes, Islamic reformism, and by modernist processes which work towards purging queer forms of affect and gender in favour of impeccably gendered heterosexual subjectivities. But I also note considerable ambivalence and tension within these moves, and argue against any teleological mappings of such moves which would - firstly - take for granted and - then - celebrate a shift from Indian 'arranged marriage' towards a 'pure relationship', founded on romantic and passionate love. Here, I engage with recent academic discussions of Western marriage, Indian middle class and Indian subaltern marriages, and conclude that many commonly drawn oppositions ('love' versus 'arranged', 'companionate' versus ' economicpragmatic', 'till death us do part' versus 'easy divorce') are representational fictions requiring sharp critique. I also address the question of moral panic around female centred households and
\end{abstract}


proffer feminist and queer critiques. Finally, I build upon work by Saba Mahmood and others who are urging Western academics to examine their own production as liberal subjects.

\section{Introduction: Love and Well-Being in a context of transnational connections}

Several writers have been concerned to trace the articulations between India's (post late 1980s) shift in economic policy and changes in social life (e.g. Mankekar 1999; Fernandes 2000; Deshpande 2003; Uberoi 2006; Thapan 2009). Others have argued for intriguing connections sometimes drawn explicitly in South Asia - between expectations of 'love' and 'economic prosperity' (e.g. Ahearn 2001) or have pleaded for us to take proper account of the correlatedness of the rise of 'sexuality' (as / in discourse) and the wider post-liberalisation economy (Mazzarella 2001; Srivastava 2004, 2007). I'm arguing here that contemporary expectations of family life, marriage and 'love' may indeed represent a break with the pre-1980s, pre-economic liberalisation India. But I am at the same time tracing continuities with older 'pragmatic-economic' forms, in as much as I also agree that somehow, the whole does need to be set within an analytic framework which would try to explore the many connections which people do clearly expect, tacitly or explicitly, between 'economic well-being' and a 'happy family life'. I will discuss the emergence of 'romance' and 'love' as adjuncts to Kerala marriage, and the shift to new ideals of family, envisaged as life-projects suffused with affective and economic labour, and how this is all buttressed by new public norms of gendering and given concreteness in new small households. We may in Kerala indeed be in a historical moment similar to that of the late $19^{\text {th }} /$ early $20^{\text {th }}$ century, when major shifts in the colonial economy went hand in hand with projects of social reform aimed specifically at gender, marriage and family, with all families undergoing shifts, and matrilineal families subjected to extreme restructuring (see e.g. Jeffery et 
al 2004; John, M. and J. Nair. 1998; for Kerala, see Jeffrey 1976; Devika 2002, 2005, 2006, 2009; Kodoth 2001). Among coastal Muslim matrilineal communities, the situation is made more interesting yet, because of the weaving in of influences coming from $20^{\text {th }}$ century Islamic reformism, a strong transnational (Indian ocean) history and a vigorous contemporary Gulf presence.

Johnny Parry wrote about the contrasting marital histories of a Dalit illiterate father (bullock driver, factory labourer) and his highly educated (BA, MA, B.Ed) and respectably employed (schoolteacher) daughter. Parry argues that, "Marriage is rapidly changing its meaning ... No longer merely a matter of the satisfactory discharge of marital duties, it is increasingly seen as a union between two intimate selves and carries a much heavier emotional freight" (2004:312). Parry theorises a rapid break and also seems to approve of the general shift towards greater marital stability and 'intimacy': he cites approvingly Anthony Giddens' (at once clearly both ethnocentric and mistaken) argument that intimacy leads to equality; he also draws an opposition between the pragmatism of the older generation, for whom financial considerations were paramount, and the expectations he discerns among younger people that marriage is not primarily pragmatic but is about love, conjugality and intimacy. When, as a 1980 s graduate student, I first heard about Giddens' 'pure relationships', I experienced a mixture of dismay and disbelief, and my negative assessment has not lessened as he has developed his arguments and they have been taken up in other academics' work (Giddens 1992): I feel dismay that the moral embeddedness evoked by sacrifice and compromise is being evaluated so very negatively and ego-centrically, and disbelief that even academics could be so apparently deeply and uncritically embedded within their own modernist liberal expectations of a 'pure love' without sacrifice, 
compromise, a little touch of pragmatic adjustment and realism, a love enmeshed in the everyday messiness of domestic duties and hidden bargainings. ${ }^{1}$ This ought not be troubling: kinship is an ambivalent relation (Peletz 2001:434) and caring is an ambivalent condition (Abel \& Nelson 1990). To be human is to be ambivalent. Academic studies of contemporary Western marriage and family are beginning to challenge idealized narratives (e.g. Simpson 1994, 1998; Kipnis 2003; see also Blum 2005 and work from the 2011 interdisciplinary 'Gender and Love' project ${ }^{2}$ ) but, as Borneman points out, until we properly study 'divorce' and severance as being part and parcel of 'marriage', the romantic myth of 'till death do us part' will hold fast even as normative model in the face of overwhelming anecdotal, personal and ethnographic evidence $(1996,2005)$. In any case, whether we name and positively evaluate it, following Giddens, as 'pure relationship' (1992), or name and critique it, following Zygmunt Bauman, as 'liquid love’ (2003), this particular form of love, shorn of embeddedness in family and the domestic, would seem indeed to stand at the opposite pole from conventional Indian expectations of marriage. South Asian ethnography, however, suggests that the contemporary situation is not ushering in so much a clear transition from one form to another, but an altogether more ambivalent and hybrid picture - which then forces us to reflect back upon the reality of the contemporary western form which putatively supplies the model for, and the extreme outlier case of, a 'pure' love and companionate marriage.

Think about Parry's example: - Janaki’s refusal of her rustic arranged-marriage partner and holding out for her chosen spouse (educated and employed as a teacher). I think we have at work here not a Giddens-style search for a 'pure relationship', but something more complex and ambivalent; an individualised insistence upon personal choice, for sure, but also a clear concern 
for a husband who will be a better domestic provisioner and a more ambitious father than the spouse chosen by the parent (Janaki's illiterate father, who lacks the competence to find and select a life-partner who will join in Janaki's future-oriented 'successful family' project).

While I certainly do not subscribe to Parry's celebratory assessment of recent changes, nor agree with all of his analysis, specifically his assessment that 'pure love' is ousting material considerations, I do agree with him that conjugality is sharply re-shaped under conditions of embourgeoisement, a process which post 1980s economic and communications shifts are helping disseminate to a wider section of the Indian population. Laura Ahearn's study of shifts away from arranged marriage and towards love marriage in Nepal supports my argument, in as much as she finds that 'love' and 'life success' are very much tied together in the search for a suitable love match spouse (Ahearn 2001), something clear also in Patricia Uberoi's recent work (2006).

Moving away from the over-represented and disputed Indian 'middle classes'

(Deshpande 2003), Shalini Grover (2009, 2011a, 2011b) has explored with careful nuance the ways in which marriage in low income low caste Delhi families is fluid, with social sanction given in these 'slum' neighbourhoods - and even by police and NGOs - to informal divorce, remarriage, and a variety of semi-formal separations and unions. She carefully tracks the ways in which a combination of pragmatic considerations (economic survival, childcare), personal desires (romantic aspirations, women's wish for relative autonomy) and contingent factors (a man's drinking habits, a woman's promiscuity) come together as the ground from which marriages are made, unmade, and often remade or re-adjusted. It would be impossible to claim from Grover's ethnography that marriage among the poor is a purely economic affair, surveying the tales of love, lust and romance that she tells; or to hold on to the old romantic-ethnographic 
idea that the difference between Indian respectable middle class marriages and those of the poor is that the former are a matter of property and family while the latter are done simply for 'love'. I'm arguing here then that the 'arranged' versus 'love' dichotomy has properly broken down, even before the emergence of recent hybrid forms (Donner 2002, Fuller \& Narasimhan 2008), not simply then as empirical description but as analytic, since all marriage across all social classes involves a mix of practical-pragmatic, economic and affectual-passionate considerations and forces. The bottom line, then, of 'love' across South Asian social classes, whether it is permitted before marriage (as in Ahearn's Nepali case) or expected to blossom after marriage (as in contemporary Kerala) is, I am arguing, continuous with older forms of marriage even as it is part of a contemporary re-shaping of conjugal expectations.

Sanjay Srivastava has suggested that, "One way of thinking about the ideas of romance and love that congregate in the present context is that they elaborate a narrative for the 'future development' of the individual; they point to the discourse of agency that is connected to the 'economic' but not reducible to it” (2004:202). While certainly not simply reducible to economics, it is clear that a tight relationship exists between economic conditions and social attitudes towards individualism, choice and 'love'. What we might be seeing then is not a shift from mixed motives to pure relationship, nor a transition from pragmatism to 'love', but the emergence of more individualized subjects who demand more say in spousal choice and a slightly different configuration of their intimate lives, while keeping hold of an understanding that marriage is a life partnership and is tied up with both economic matters and the raising of children. Childcare, Borneman (2005) claims, is globally a more relevant issue in marriage and household strategies than is economic provisioning or sexual partnering. Children are also 
central to marriage in as much as they become, in contemporary global capitalist societies, the prime target of fantasies about futurity and success, economic well-being and social status; children also, of course, offer parenthood, generally a chance to consolidate an impeccably normative mature gender status ${ }^{3}$ (Edelman 1998; Patel 2006; C. \& F. Osella 2006).

At the same time as I explore here love as part of new family forms, I am also interested in untangling some of the ways in which modernity's 'love' is configured as a blend of exclusivity of affect, (hetero-)sexual desire, and 'correct' gendering. Giddens' assumption that 'gay love' represents the most easily traversed path towards the desired pure relationship is empirically naïve and is, for me, a clearly recognizable case of the idealization which the straight normatively gendered man often holds for his disavowed and abjected other. Moreover, Giddens' story of disembedding completely overlooks the processes traced by feminist and queer writers by which 'love' and 'desire' repeatedly come to the service of the norm (Rubin 1975; Langford 1999; Warner 2000; Povinelli 2002; Kipnis 2003 ${ }^{4}$ ). Like 'sexuality', 'love' is indeed inextricably tied up with modernity's production of manageable subjects, the production of such (gendered, sexed, sexualised) subjects being a process which, as queer theory (following Foucault 1990, Butler 1990) has exhaustively shown (e.g. Sedgwick 1990) has been one of straightening out humans' tendencies to be bent. Even if, as Boelstorff has argued, gay marriage is not the same as straight marriage, because it can be argued to take place perhaps in 'queer time' rather than 'straight' time (2007; cf. discussions in Dinshaw et al 2007), still 'love' far more commonly becomes a means of producing modernity's gender normative, driving out and delegitimising queer gender forms, and the older forms of sociality and relationships within which these forms flourished; this process appears to be in full swing in Kerala. 


\section{'Old families, new families'}

Turning to Kerala, the 1930s saw (colonial and nationalist) critiques of existing forms of household and sexual liaison (notably the infamous 'Nayar marriage', wherein women in matrilinies hosted multiple visiting lovers, see Jeffrey 1976; Fuller 1976; Kodoth 2001; Arunima 2003; Devika 2006); the 1960s, with the introduction of artificial birth control techniques and state planning, pushed more sharp re-workings of marriage (trajectories carefully traced out by Devika 2002, 2005); most lately, processes of economic liberalization and Gulf migration are provoking another moment of upheaval. Among Muslims, the growth of an educated reformist vanguard is proving crucial to the way in which these shifts are working through.

Something that is making Calicut's Kerala Muslim families especially interesting in these discussions is their long histories of transnational engagement, enabling us to think beyond the usual South Asianist's analytical straight-jacket frame of the national arena and the influence of colonial or post-independence state policy (e.g. Chatterjee 1993; John and Nair 1998; Jeffrey 1993). Unlike the majority of Kerala (or Indian) Muslims, Calicut ${ }^{5}$ s Koya Muslim community describe themselves as a marumakkatayam (matrilineal) community whose exclusive status is maintained by generalised endogamy. They are a trading community living in a zone around the bazaar, and claiming mixed India-Arab descent, a pattern familiar across Indian ocean coastal trading societies (Parkin 1989; Stivens 1996; Blackwood 1999, 2005; Simpson and Kresse 2007).

In Calicut, marriage and prosperity have long and very self evidently gone along together: visiting Arabs were able simultaneously to make alliances with local trading partners 
and to take local wives. Calicut Muslims' systems of family, household and marriage are all intrinsically linked into the town's history as an Arab trading port and to longstanding kinship links with Gulf Arabs, be they traders or sailors (F \& C Osella 2007, C \& F Osella 2008b).

"Arabs were very well received and respected by the Zamorin rajah who gave them land, allowing them to settle. At that time, Arab merchants and sailors had to stay here for a considerable time; they were away from home for many months and so they married local ladies, mut'a." 6 Belonging to a matrilineal tharavadu stands for claims to Arab descent and to an early peaceful conversion to Islam via continuous trade with the Gulf. Urban tharavadus also index claims to higher status (trade) than patrilineal Muslims (fisherfolk, labourers, inland agriculturalists). Land prices and pressure on the land in the neighbourhood around Kozkikode's bazaar, where the tharavadus stand, has become intense. The neighbourhood is roughly bounded by the sea coast and beachside warehouses, the bazaar, a river and bridge, and the railway and is densely populated. Large two-storeyed tharavadus, most of them built in the late $19^{\text {th }} \mathrm{C}$ colonial trading boom, already commonly have many sub-buildings, extensions, even semi-legal mini squatter settlements, in their grounds, behind their high walls, making further extension impossible. Restoration and renovation is costly - more costly than new build; and most tharavadus are by now enmeshed in complex webs of multiple ownership and rights, often disputed. But it is only partly because of these pressures that many men are nowadays building homes outside of the neighbourhood. For new family forms are arising, which demand new ways of arranging domestic space.

Islam of course prescribes patrilineal inheritance. This tension has been only partially resolved by the combination of matrilineal practices with shari' $a$ inheritance, and has become 
quite acute recently, following reformist campaigns for the adoption of 'true' Islamic practices. While all Kerala Muslims are Sunnis of the Shafi school, these days the term 'Sunni' means 'orthodox' or 'traditionalist' Muslims who stand opposed to organised reformists. In Kerala, the two biggest sectarian groupings and the most culturally salient distinction is that between the Sunnis and Mujahids.

Mujahids themselves admit to having only $10 \%$ of Kerala's Muslim population as followers, but claim to have a far greater influence across Kerala Muslim life. It is true that the reformist and modernising impulses promulgated by Mujahids have since the 1920s set the agenda for the direction of the community in general (F \& C Osella 2008b). It is essential to note that the Mujahid movement is home grown, despite many external influences. At the same time, it is often while working away in the Gulf and newly-dependent on Kerala Muslim networks that migrants get exposed to and become adherents of the Mujahid tendency. It is plain that the rise of Islamic reformism in no way forces austerity upon people, as might be assumed by some Westerners, accustomed to the cultures of Protestantism and hearing the (mistaken) arguments about reformism framed as a type of 'protestantising Islam' (F \& C Osella 2008a). Desire and pleasure are here permitted - recognised as legitimate aspects of human experience. But naturally, desire must be negotiated within a framework of morality (Metcalf 1984; Perneau 2003; Jeffery et al 2004). In Calicut, this takes on a very self-conscious modernist / Salafi-reformist tone.

Islamic reformism is one of the strong influences at work in the critique of matriliny. Reformists argue that the tharavadu system fosters a lack of responsibility in men, since wives and children are accommodated in the matrilineal home, where mothers and brothers will see 
that women and their children will never starve, even if a woman's husband is feckless.

Reformists object to tharavadus being in women's names and passed down only through and to women. Reformists also worry that matriliny does not allow for a proper modern Islamic moral family to grow, since men are not spending enough time in the same domestic space as their wives and children. Men, daytimes, take lunch in their natal home or a meals hotel; in the evenings, they are out on the streets, with friends, especially between Maghrib and Isha prayers. To be sure, they are attending five times prayer, observing ramzan fasts, giving zakat and so on; but the goal of Mujahid reform is to go beyond these formal requirements of the faith and into a re-shaped self who lives the whole of their life as a good Muslim (cf. Hirschkind 2006; Mahmood 2005; F \& C Osella 2008a). Reformist critique then echoes the assumptions about family and marriage which Evelyn Blackwood in her review article identifies as modern and globalizing and as rampant even among (perhaps - thanks to the legacy of kinship studies especially among!) anthropologists - an anxiety about household and family forms in which the (heterosexual, patriarchal) man appears to be 'missing' (Blackwood 2005).

Another (though generally unspoken, subject to taboo, within Kerala) fear here is also the queerness of the forms of homosociality permitted and made structurally feasible under matriliny (F Osella in press). As Filippo and I (not uniquely) have argued elsewhere, India as a whole is in a moment of transformation of intimacy, in which long extant queer forms of desire are being purged out of many spaces, in favour of a new hetero imperative for the majority and a configuring of both 'global gay' and 'ethno queer' (inevitably stigmatised) minoritarian identities (C. \& F. Osella 2006; Khanna 2007, 2009; Gopinath 2005; see Boyce 2007 and Cohen 2005 for ethnographically located discussions of complications within or dissidence to this 
process; and cf. Altman 1996, Sutton 2007, Jackson 2009 for discussions of the rise of the 'global gay'; Boelstoff 2005 and Jackson 2009 for overviews of wider Asian trends). The persistence of Calicut's rich culture of male same-sex friendships, love affairs and sexual liaisons is an open secret, even within the wider space of India (Merchant 1999). This is becoming increasingly embarrassing for some. A switch to a neo-patriarchal household is one way for men to make performances of impeccable heterosexuality and masculinity (C \& F Osella 2006).

Some men, who have both the capital and the will, are choosing to buy or build small new homes and abandon the tharavadu.

The residential practices in tharavadus - where men have little rights or responsibilities in the property and where they shuttle between their natal home (daytime) and their wife's home (night-time) is becoming embarrassing for some men, who increasingly aspire to a home of their own. The term used in the community which gets translated into English as 'husband' is puthiya pilla, literally the 'new boy', a term which indicates the degree to which men in pre-reform matrilineal households were not configured as substantial members of the post-marital home, but were incomers whose status remained always rather marginal (see F Osella in press for a detailed discussion of men's position in the matrilineal family and their contemporary evaluations of it). While Blackwood points out that men in matrilineal or matrifocal situations are often actually central in their natal households, in Calicut, the material practices of tharavadu life enact a generalized male marginality to the household - in effect, men belong neither to their own natal home, which is the province and inheritable property of their mothers and sisters, nor to their wives/mother-in-law's home, where they also hold no inheritance rights and remain always a guest - albeit (sometimes ostensibly) an honoured one. In classic tharavadu living, a man 
arrives at his wife's house for late evening dinner and leaves after breakfast. As Filippo Osella discusses, a man belongs out of the house - in the bazaar, warehouse, mosque, tea-shop or public street (F. Osella, in press). As Blackwood notes, however, that men should be both central and dominant in the home is only a normative assumption and not in any way a universal and structural necessary requirement . This assumption, increasingly taken up by Malayalis themselves over the $20^{\text {th }}$ and $21^{\text {st }}$ centuries, would pathologise or make problematic, or in some way configure as 'missing men' or 'delinquent men', a situation in which relationships and household management revolve mostly around women, usually mothers and their daughters (Blackwood 2005). While Borneman (2005) challenges Blackwood, asking what we lose when we sanguinely accept male marginality to processes of child-rearing, I analyse Islamic reformist males' publicly expressed anxieties about matriliny more as expressions of a desire for more power and status in the household than of a desire to be more involved in either nurturing service or domestic duties. As one young reformist man who had divorced from his tharavadu marriage and opted for a second marriage with neo-local virifocal household (with a woman from an inland patrilineal family) told me, "You get no respect in the tharavadu really, it is your wife's place".

Increasing mass exposure post 1970s migration to the practices of Gulf Arabs, which include strict patrilinearity, widely visible performances of masculine control and power, and specific (very different from Kerala) styles of using both cash and time in a very family-focused manner, is undoubtedly another of the influences at work here. The new 'small family' style is not, I suggest a straightforward mimetic appropriation of Hindu and Christian middle-class styles, nor North Indian styles, as seen on TV, but picks up on ideas about 'family life' which are 
learned or observed in the Gulf. Andrew Gardner (2011) points out that Gulf states' migration and visa policies have helped to materially re-configure 'family' in South Asian practice as nuclear-patriarchal rather than extended. I would add that Khaleeji (Gulf Arab) husband, wife and kids can often be seen out together window shopping in the mall, picnicking in a park, or having ice cream in a smart café. These are the kinds of practices which I have witnessed coming into Kerala, and they have clearly not come in as part of post 1990s Indian economic shifts, but emerged much earlier, and as part of an at first self-conscious but now increasingly confident public performance of the 'modern' family. Gulf Arabs - who first brought Islam to Kerala, who appeared in Kerala as sophisticated and wealthy trading partners, and who are now living as Malayalis' employers and patrons in a developed consumer paradise - hold considerable symbolic capital for Malayali Muslims. Gulf forms of sociality can also feel like a good 'fit', suitable by virtue of being uninflected by either the permissive laxity of non-Muslim urban styles or by the restrictive purity practices of Kerala orthodox Hinduism (which, for example, makes eating out a less popular and more fraught practice for Hindus wanting to index and practice ‘modern' conjugality or familial style, C \& F Osella 2008a, 2008b).

At the same time, a deep ambivalence towards tharavadu life is widespread; it is at once cherished and abhorred. Many young women are keen to assert themselves as educated and progressive mothers, moral guardians of the family and industrious helpmates to their husbands. This empowered / impeccably modern subjectivated position is hard to reach in the matrilineage, where older styles of domesticity prevail and where women in their sixties and seventies rule the household in often fairly chaotic style. While Koya women are not expected to work for income, they are increasingly expected to become systematic, to use their time well; 
and Calicut is in the grip of a boom in handicrafts, cookery competitions and public (women only) meetings about matters of good domestic management or childcare (cf. Jeffery et al 2004, Perneau 2003). Young women enrol their kids in English medium schools, help their husbands save towards the purchase of their own house (sometimes by secret and intensive industry, such as taking on sewing or cooking as home-work) and dream of a future where their sons' employment horizons will spread far beyond the bazaar or low-level Gulf migrant labour. Women sometimes expressed their impatience to me with living under their mother's roof, and their desire to run their own home, be mistress of their own kitchen, keep the house according to their own expectations of domesticity. They shared with me their frustration of having to ask their mother's permission to go out of the house for shopping, and their anxiety about the depth of the love which their children felt towards grandmother, at times expressed in terms of a frank preference for granny over mamma. Some young women feel resentful that older women have leisure and power, making the younger tharavadu women take on large amounts of the more unpleasant domestic work, such as laundry, while the older women keep for themselves the more enjoyable and prestigious tasks which attract praise from menfolk, such as cooking.

But it is also true that many young women enjoy the matrilineal family and are clear about its benefits. They join their elder female relatives in open appreciation of the system - an appreciation sharpened by their post 1990s exposure to Hindi sas-bahu (mother-in-law and daughter-in-law) daytime TV dramas - and were often keen to point out to me its advantages over my own double-burden domestic arrangements (cf. Wadley 2010). I also heard several complaints about the problems experienced during migrant husband's (usually biennial) visits, when women find themselves stressed and pressured by the additional energy, time and attention 
that they need to give up to a man, over and above their usual domestic and familial emotional and time demands. The (usually biennial) vacationing migrant husband's tours and outings are not always welcome, either. "When he comes, we have to look after the kids and do what he wants - to please him. It is exhausting for us, we actually hardly enjoy these 'holidays', it is no leisure for us", is a typical comment.

In one Calicut matrilineal joint family house, a group of women between 19 and 70 laughed ribaldly and challenged me, "Well, so long as you have a husband's money, what else do you need? Tell us, do you really need a man for anything else??!!”

While the rather negative and normative study of Zachariah et al (2003) does not differentiate between "Gulf Wives" (GW), it is clear that in tharavadus, the practical and emotional support of sisters and mothers (and a man, be he father or brother, for of course not all men are away and every matrilineage has men affiliated to it, albeit not as patriarchs cf. Blackwood 2005) is available and appreciated for stay-behind Gulf wives, enabling them at once to overcome loneliness and manage added responsibilities such as dealing with banking or children's schooling. It is interesting that the solution envisaged by social policy and popular press alike to the much-pathologised bogey-figure of the miserable or errant 'Gulf wife' is an end to migration and a return (or shift) towards a nuclear household in which a man takes his 'proper' role. Like the moral panic in the US over female-headed households (also discussed in Blackwood 2005), the pathologising of the Gulf Wife and the identification of 'Gulf Wife syndrome' can countenance only one solution ${ }^{7}$.

Many Calicut women indeed feel reluctant to move into a new 'small house' where they will no longer have the company and domestic help of their mothers, sisters, aunts and cousins, 
but will be the sole domestic worker, deprived of continuous female company and under the rule of their husband rather than their own mother. One woman in her 40s looked downright miserable as she and her husband showed me around the new 5 roomed house he had bought. He was imagining himself finally master of his own home, rather than guest in his wife's tharavadu; she told me that, more than the increased workload, she was dreading the loss of company - for her husband would be out at work as usual for long hours at the bazaar and then out socialising with his male friends after evening prayers.

Even some younger men choose the benefits of the tharavadu. While the discourse of 'local custom' or culturally specific adaptations to Islam (adab) as permissible is usually rejected by reformists, when it comes to matriliny, an exception is often made (see F Osella in press for fuller discussion). Women are also turning in several directions and we can trace the coexistence of many trends which are utterly opposed to each other. We have at the same time a defence of and even a folk-ish nostalgia for the old fully joint tharavadu system, even as it is on its last legs, along with a condemnation of it as not conducive either to proper conjugal and paternal love or to economic progress.

\section{The contemporary Gulf in the Kerala household}

I have written elsewhere about the rejection by most women of Kerala's older style pardah and the take-up of the abaya (C \& F Osella 2007). The Gulf here plays a part as a source for contemporary Muslim fashion trends, and as a filter-space where global consumer goods can be both accessed and also assessed for their conformity to Islamic decency.

The arrival of a 'door to door' is a moment of great excitement in any household. These 
parcels, couriered from Gulf-based husbands, are of enormous importance in evoking the love which an absent man holds for his wife and children. Parcels contain gifts and also household items which are to be put away ready for when the couple shift to their own new house. Along with useful consumer goods (e.g. mixer-grinders), items which are not used in Kerala - kettles, toasters - are sometimes sent. Such items are able to allude to the modern domestic lifestyle imagined in the planned 'small house', while being cheap and easy to buy in supermarkets like LuLu or Carrefour. A man may not be up to sending a washing machine or flat-screen TV, but a toaster does essentially the same symbolic work for him and his wife, of calling up for them their imagined future in their own independent kitchen, where drudgery over a stone grinder or washtap will be replaced by deployment of consumer electricals. Gifts also, as I have argued elsewhere, metonymically replace the man's presence and act as extensions of his masculine (earning) power, ensuring that even at a distance, he continues to reach into the house (2000: 138ff).

Apart from electricals, clothes and shoes for wife and kids and some luxury goods such as perfumes, parcels often contain food items. Huge tins of Nido dried milk and Tang orange drink powder are much appreciated back home and generally shared with the wider household. What is less likely to be shared are the 'special' foods intended particularly for a man's own children. One mother told me that her husband knew that his daughter never wanted to eat breakfast. He had sent a large box of cornflakes, with instructions that these could be taken with Nido dried milk. When I next popped by, I saw the daughter happily eating cornflakes exactly as they were presented in the 'serving suggestion' photo on the box - with milk and strawberries. Eager to taste the full-on breakfast, mother had visited a fancy fruit stall to buy imported (from 
Ooty) fruit. Here, it is beside the point that cornflakes are easily available in Calicut or that strawberries are an outlandishly costly item. The point is that breakfast in a tharavadu usually means (female labour-intensive) fried breads and curry; cornflakes evoke a quite different lifestyle. The parents have, through father's gift and mother's careful attention to 'serving suggestions', tried to offer their daughter the very best of modern consumer treats, aimed at shaping her into both bodily strength and modernity and re-working the family unit into a different type from the tharavadu family: into a small group of individuals bonded by love, where children are cherished, modern, deserving of 'special' treats and so on, and where mothers and fathers lovingly join in forging their 'small family' project of social mobility.

The shift towards the 'small family' as the normative site of pleasure and companionship is clear when we think about the commonest four types of group which come on Saturday or Sunday evening to Calicut beach, where crowds throng to walk, watch the sunset, buy snacks and maybe go afterwards for faluda at an ice-cream parlour. A walk on the beach, admiring the Arabian sea, is a cheap form of entertainment available to all and, unlike the costly tours mentioned above, invitations to join a group do not need to be limited. On the beach, we find large groups of womenfolk from a tharavadu with all their children; given the size of the group (maybe 5-10 women) and the presence of older women, no man is necessary for chaperone here, nor indeed is one usually present. This is a practice which is apparently longstanding: while nowadays crowds arrive from $4 \mathrm{pm}$ onwards, oral history recounts to us that women used to come out in groups after dark to the beach, where they then felt relatively screened from male view or public censure. The second set of groups that we will always find on the beach is made up of young men (maybe $4-15$ of them together) enjoying each other's company while they 
also look surreptitiously at girls, cruise for sexual adventure with older men (or combine both activities). Then we can see some much smaller groups of older men in the company of a few friends; they may be chatting companionably, or cruising young men. Finally, we also see plenty of nuclear families, fathers buying balloons and paper screws of peanuts for the kids, chatting with their wives and sharing smiles at the kids' joy and antics. The contemporary thrust would see all the first three types of group replaced by the latter; presumably the older men and women in the first and third groups, enjoying the comforts of a same-sex social outing, would have to find their place as 'granny' or 'grandad' in one of the nuclear family groups - or be left at home. The groups of young men - of course, the most demonised of all those whose practices are now suddenly deemed unmodern and/or immoral - would have to take their place, meanwhile, as junior males, no longer free to roam and challenge social convention (C \& F Osella 2006) but now constrained to pass their free time in mixed groups and to act according to public morality, under firm eyes of elders and the presence of their own fathers. Women would be pried out from their large homosocial groups and re-situated not as 'daughter' or 'grand-daughter' but as 'mother' and 'wife' and as firmly under husband's control and care. Presumably, the women whose husbands are away in the Gulf would simply stay at home, along with their children, if there were no nearby grandfather to take them out; her brother would, of course, be occupied with his 'own' family. While brother and sister obligations and affective ties are cultivated and expected to be intense in tharavadu living, in a new 'small family', a man is expected to turn towards his wife. 


\section{Negotiating desire and morality}

Transformation of one's intimate life is not merely a moral duty, since it is also part of a desire for the modern. This encompasses a keen desire to assert self-respect and escape the continuing critique of those Hindu communities (like the Nayars) who abandoned matriliny in the colonial period (see e.g. Fuller 1976; Jeffrey 1976, 1993; Devika 2006, 2007); but it is also powerfully shaped by aspirations towards that 'modern' family lifestyle which opens up new spaces and earmarks time for consumption and leisure. This returns me to my opening remarks about the explicit links which seem to be able to be made between (heterosexual, conjugal) 'love' and 'economic progress', and points towards work which thinks through the ways in which the disciplining forces producing good consumer citizens works right down into the realm of the intimate (see e.g. Patel 2004, 2006; Mazzarella 2001). But these are not processes which proceed straightforwardly (cf. Filippo Osella in press for discussion of the ambivalences among menfolk).

Wedding videos are highly condensed sites where both fantasies and conventions are woven together and where romance, glamour and lavish spending are always expressed within idioms of the local, the authentic, and are situated firmly within the control of the moral family. Contemporary video-makers take bride and groom out to some beauty-spot a day or two after the wedding, and encourage the pair to 'act out' a fated romantic connection. In one such that I was shown, the groom was placed sitting pensively on a fallen tree trunk. His bride wore make-up usually an item considered utterly haram - and was dressed in her mailanchi night choli $^{8}$, with hair loose and hidden only perfunctorily under its flimsy shawl. She was made to run towards the groom, provoking some embarrassment among us women who sat watching the video as we 
noted how her breasts swung for all to see on film. Still, no matter; the romance, glamour and sexuality being presented here were intended for the husband, and the video was a site where husband and wife were encouraged to imagine themselves as filmi lovers. Re-watching a wedding video with one pair of sisters, the younger woman (the recent bride) called out, "I love you!" whenever her husband appeared on screen. Not to be out-done, her elder sister, whose husband is a Gulf migrant and comes home infrequently, blew noisy kisses to her husband (of 10 years) when he came into shot. Knowing these women well, and having talked often with them about their husbands and their (arranged) marriages, their actions at that moment seemed to me at once ironic, sincere and expressive of longings unfulfilled. If we refuse to follow Giddens' liberal sentiments, and if we refuse the move - at once Orientalising and self-deluding - of imagining 'Western' love realities as accurately described by the fantasy model, then we need feel no anxiety at such hybrid and mixed feelings, nor hope for teleological 'progress' involving purging and resolution in the direction of a 'pure' love.

All this 'love discourse' is radically different from older (pre 1990s) wedding photographs and videos, in which the newly weds are not at all expected to behave like lovebirds, much less demonstrate sexual attractiveness or attraction. Giggling embarrassment (her) and tender-hearted good intention (him) are the sort of expressions I see in my collection of wedding videos from the 1980s. Going back to the 1950s and 1960s, poised detachment and (often feigned, to be sure) indifference are what I observe in wedding album photos. The recent explosion of, first, 'love' (1980s) and now, 'sex' (2000s), in wedding videos seems to me to be related to the forswearing of the older matrilineal joint family and expansive homosociality and the energetic cultivation of a new style of conjugality and gendering. 
Many wedding videos play as their backing track oppana pathu, folk wedding songs sung in a special 'Muslim language' particular to Kerala's Muslims (M N Karassery 1993). Here, frank nostalgia for old style 'authentic' folkness often appears, dressed up in a TV-serial / filmi aesthetic. The loss/sacrifice of matriliny - the matriliny which has up until now acted as strong signifier of Malabar coastal Muslims' cultural superiority and distinctiveness (see e.g. S M Koya 1983) - is perhaps demanding that other tropes arise or are developed. The craze for Mappila pathu and for the staging of oppana performances at both public functions and at 'posh' weddings - a craze whose growth has been facilitated by post 1980s technologies - bleeds into recent wedding video aesthetics.

In the spacious and expensively renovated tharavadu of one Gulf family ( 2 sons in Gulf; 4 sons-in-law in Gulf), I was shown a wedding video in which all the bride's family womenfolk acted out for camera (some sheepish with embarrassment, most enthusiastic and a few giggling with the fun of it all) an oppana performance; the bride sat on a chair while all her female relatives danced in a circle around her, clapping and singing along to classic oppana songs, which, for example, sing of Khadeeja or Fatima as ideal models for the bride to follow. But of course instead of wearing the traditional simple older woman's white cotton cloth (kacci kuppayam), as all stage oppana performers do, making a glorious contrast to the bride, in this wedding video all the women (new bride included) were dressed Gulf-family style, in bright silk saris heavily embellished with stones, embroidery and even Swaroski crystals. The effect was similar to that of the glamourised and romanticised village in an Indian movie (Dwyer 2000). As we watched this wedding video, ambivalence again surfaced: women were at once proud and keen to show me the opulence and 'tradition' on display and resist critique of families like their 
which cling to large female-headed households; and were also slightly sheepish about what we all tacitly knew was the inauthenticity of this real-life oppana performance ${ }^{9}$.

The wedding videos index two major sources for the new ideas of feminine glamour and beauty: visual media (especially North Indian daytime tv serials) and what women have observed - or had reported to them - from the Gulf, as the style of Arab women.

Malayali women and men alike are keen to deprecate the morality of Arab women. The charges made against them are legion. Some are issues concerning an alleged failure to observe Islam correctly. Calicut Muslim women do not use cosmetics, including nail polish, and are convinced that these items are haram. Many women explained to me that you cannot do your ritual ablutions correctly if nail varnish or make-up are covering and blocking water from reaching the body. But at the same time, the critique of make-up is not simply a technical one (after all, 'Islamic' makeup has been invented in the booming marketplace of Islamic consumerism, see e.g. Abaza 2006). Makeup also plays a part in an opposition drawn between women who are 'simple' and those who are not. Simple here is a positive moral attribute which becomes a widespread goal especially (but not uniquely) appropriate to women across South India, among all religious communities. Malayalis are accustomed to compare themselves and their women favourably to certain categories of North Indian women ('Gujaratis,' Punjabis'), who are often accused of being spoilt (impure) - makeup, smoking and drinking, boyfriends. All sorts of vices are mentioned as not having - yet - penetrated South India. In Kerala even small girls will be dressed with a careful eye to modesty; sleeveless, for example, is not felt suitable for any female over about 5 (C \& F Osella 2007b). The lingerie and nightwear in Calicut's bazaar is overwhelmingly functional and modest, with few takers for the racier styles; women here have 
not been drawn into the modalities of sexual subjectivations now utterly normative among contemporary Westerns (e.g. McCaughey \& French 2001) or alluded to as emerging in metropolitan India by Srivastava (2007) or Phadke et al (2011), or in the Middle East ( e.g. Syria, see Halasa \& Salam 2008) and the Gulf ( al-Qasimi 2010). Arab women, with their high glamour and their easy access to freedom of movement (cars with drivers) and to luxury, appear as utterly corrupted and the diametric opposite of the South Indians' precious and jealously defended reputation for being simple, and reformist Muslim women are those who most carefully guard their 'simplicity'.

Yet Arab women are also acknowledged as fabulously beautiful and glamorous, both by nature (pale skin, sharp features) and by artifice. Many Kerala men now wish to attach some of this glamour to their wives, as hinted towards in their private luxury gifts of cosmetics and perfume. Men sometimes send or bring cosmetic boxes home to their wives, but the lipstick or eyeshadow can only be used in the privacy of the marital bedroom and must be washed off even before appearing before other family members (if it is used at all; I have been shown these boxes by some young women with amusement that their husbands thought that they might use such an item, under any circumstances, no matter how private). The tension between women's imperative to perform reformist morality and South Indian simplicity on the one hand, and both women and their husbands' accelerating desire for a more glamorous style of femininity on the other, does not seem to have yet found itself a clear way out.

$\mathrm{TV}$, films, Gulf lifestyles are all carefully watched for the styles they offer in family organisation, use of leisure, domestic arrangements, fashion and so on, but are all also monitored for excess. Islamic reformism is helping assuage anxieties about entry into a consumer society 
and a world of small families, as it guarantees morality and even underwrites some desired-for changes - such as the advent of the neo-patriarchal small household - as being properly expressive of a global Islamic modern. This compares to Srivastava's (2007) discussion of subaltern Hindus' confidence at their ability to negotiate contemporary capitalism, in contrast to an attitude often reported among the Hindu middle-classes as frankly anxious, e.g. Fernandes 2000; Van Wessel 2004).

\section{Conclusions: keeping 'love' in its proper place}

When Filippo and I returned for a short trip to Calicut in 2007, we found dramatic developments underway. Between $2006-7$, there were two suicides within the tightly closed community around the bazaar. These were of married women with husbands in the Gulf; these women had absconded with lovers, then been caught and dragged back to Calicut. Recriminations were violent, suicide the end result. Some people hinted to us that these 'suicides' may actually have been forced. A degree of Schadenfreude and a clear desire to distance the self from these transgressing women was evident in many women's discussions about the situation, where I perceived a salacious relishing of details, a genuine horror at both the women's behaviour and at the family reactions, and a bewilderment as to why any woman would risk everything 'just for that thing' (sex). Discussions of adultery also prompted women to speak to me about the fact that there had also been a recent spate of love marriages within the community, some of these with Hindu young men. Anxious discussions and accusations of what was named 'love jihad' (cross-community marriages and conversions) took place in the public sphere ${ }^{10}$. The 'love jihad' discourse clearly brings together a variety of anxieties such as safety, threat, communal 
tensions, Islamophobia and Hindu dominance, morality, and the dangers of both emergent individualizing subjectivities and the rise of 'love' as a new imperative.

The community as a whole has begun to turn away from its previous policy of keeping tight secrecy on such issues; in 2007, a 'family life' public meeting was called by (mostly male) Islamic reformists to discuss how best to address these issues. Unsurprisingly, blame is laid upon 'the Gulf', 'westernisation' and the influence of global media. That an energetic local promulgation of nuclear families and the rise of discourse about 'love and sex within marriage' might have knock-on effects in the guise of 'love and sex outside of marriage' does not seem to be considered. Meanwhile (and interestingly, if not surprisingly), what I have also delineated as important, viz. the purging of queerness and the work being done right now to suture gendering to (hetero)sexuality, is not up for public discussion (see F Osella in press).

While men seem right now to be generally afraid and anxious, and seeking in various ways to exercise greater control over women, women themselves are resentful and angry with those women whose actions are now having consequences for all Calicut Muslim women. I heard no sympathy or empathy expressed among women anywhere for either the runaway brides or the adulterous women. Women committed to Islamic reformism spoke of the need for more moral (by which was intended Quaranic) education for women; women not so committed spoke of the need for a collectivist sensibility, in which individual women would realise that their actions impact upon all women, and would hence become considerate and act with more circumspection. Women strongly criticised the irresponsibility, selfishness and lack of foresight of those women who had taken part in 'romance'. Such women, I was told, were not thinking about the risks and the future impact upon themselves and others of such a course of action, nor 
were they acting pragmatically. Women told me that of course it is normal to have 'boyfriends' before marriage ${ }^{11}$, but to imagine that this could continue in later life is madness. The renunciation of individual desire and 'love' in favour of agreeing to parental choice and arranged marriage was, women agreed, all part of the normal life trajectory; to try to make a marriage out of teenage 'love' was foolhardy (cf Joseph 2005). As with my earlier research work among rural Hindu women, even those who had done 'love marriages' (I met one such woman in Calicut) openly told me that they regretted it, and that the stigma and the loss of family/community material and social support, had not been worth it. Meanwhile, women expressed strongly the view that to embark upon an extra-marital affair with an outsider to the close family was sheer idiocy. The example of the 'too free' and 'too glamorous' Arab woman appeared sometimes as negative moral example in these discussions of where one could end up. The heterosexual desire and love which is being introduced and cultivated around Calicut is clearly understood, as the wedding videos suggest, as something which must be firmly embedded within the safety, stability and morality of marriage and a wider family group.

Interestingly, the role of Muslim young men themselves in initiating 'romance' and the widespread participation of older Muslim men in extra-marital affairs and in engaging sex workers (male and female) was not brought up at all by any of our research respondents. When Filippo raised the issue with those with whom it was possible to speak of such matters, men abruptly changed the subject and refused to engage in any discussion of men's part in 'illicit' behaviours, or even to respond to Filippo's suggestion that a degree of hypocrisy and double standard was operating (F Osella in press; cf. Devika 2005, 2009).

When I raised the issue of men's hypocritical moral panics with womenfolk, they would 
remark that, "Men are all like this [i.e. 'sex mad'] and they think we are too, so they always put all the suspicion and control on us". Yet at the same time, women neither confront nor blame men, and continue instead to blame other women for their role in provoking male suspicion and anger and hence for precipitating greater control on all women. In line with what has been explored with regard to male violence in Pakistan (Ring 2006), it seems that women in Kozkikode are accepting men, 'just as they are', and rather than cultivating hopes or expectations for men to change, they are placing the onus on other females to adjust to and manage their relationships with men. This necessarily includes socialisation of daughters.

One reason for the phenomenon of the eruption of 'love marriages' and adultery would seem to be growing expectations of what marriage should entail and hence a greater potential for dissatisfaction with pre-existing styles of marital bond. Yet most women choose to pursue the path of virtue and conformity to expectation, from a mixture of conviction (that this is the right way), pragmatism (that this is the only liveable way) and indifference (how important in your life is your husband anyway?). The generation of women aged $25-40$ are in between old and new family styles, raised on the cusp of matrilineal homosociality and neo-patriarchal conjugality, and accordingly embody considerable ambivalence.

Finally, Evelyn Blackwood's review of anthropological discussions of matrilineal kinship and matrifocal families supports arguments, following feminist analyses of kinship such as Janet Carsten (2000, 2004) Sarah Franklin (2001) or Marilyn Strathern (1992, 1996, 2005), that we cease to work outwards from terms of assumed universal relevance, 'heterosexual marriage' being one such, and instead pay attention to the ways in which relatedness, caregiving, and attachment are configured in particular locations. From this stance, taking 'marriage' as both 
analytic focus and as an assumed necessity in the formation of households and the careful raising of children indicates nothing so much as anthropology's continuing complicity with the dominant (heteronormative, neo-patriarchal) discourse of modern western society. Imagining 'love' as then at once both necessary to marriage and as a positive or 'pure' force working progressively to replace pragmatic considerations of childcare and provisioning indicates the degree to which anthropologists themselves remain in thrall to - and lamentably unreflexive and uncritical of - the paradoxical means by which they themselves have been produced as liberal desiring subjects (cf. Mahmood 2001, 2005; Joseph 2005).

\section{References}

Al-Qasimi, Noor. 2010. Immodest Modesty: Accommodating Dissent and the 'AbAya-asFashion in the. Arab Gulf States. Journal of Middle East Women's Studies, Volume 6, Number 1, Winter 2010: 46-74.

Abaza, Mona. 2006. Changing Consumer Cultures of Modern Egypt: Cairo's Urban Reshaping. Leiden and Boston: Brill.

Abel, Emily K., \& Nelson, Margaret K. 1990. Circles of care: Work and identity in women's lives. New York: State University of New York Press.

Ahearn, Laura. 2001. Invitations to love: Literacy, love letters, and social change in Nepal. Ann Arbor: University of Michigan Press.

Altman, Dennis. 1996. On Global Queering. Australian Humanities Review, July 1996, http://www.australianhumanitiesreview.org/archive/Issue-July-1996/altman.html. Accessed 31.1.12.

Arunima G. 2003. There Comes Papa: Colonialism and the Transformation of Matriliny in Kerala, Malabar c. 1850-1940. New Delhi, Orient Longman.

Bauman, Zygmunt. 2003. Liquid Love: On the Frailty of Human Bonds. Cambridge: CUP. Blackwood, Evelyn. 1999. Big Houses and small houses: doing matriliny in West Sumatra. Ethnos 61,1: 32-56. 
Blackwood, Evelyn 2005. Wedding Bell Blues: Marriage, Missing Men and Matrifocal Follies. American Ethnologist 32,1:3-19.

Blum V. L. 2005. Love Studies: Or, Liberating Love. Review article in American Literary History 17(2):335-348.

Boellstorff T. 2005. The Gay Archipelago: Sexuality and Nation in Indonesia. Princeton, NJ: Princeton Univ. Press.

Boelsrorff Tom. 2007. When Marriage Falls: queer coincidences in straight time. GLQ $13: 2: 227-248$.

Borneman, John. 1996. Until Death Do Us Part: Marriage/Death in Anthropological Discourse. American Ethnologist 23(2):215-235.

Borneman, John. 2005. Marriage Today. American Ethnologist 32(1):30-33.

Boyce, Paul. 2007. Ambiguous Practices: Sexual space and Spatial Sex amongst Men who have Sex with Men in Calcutta, in (eds) Bose, Brinda / Bhattacharyya, Subhabrata, The phobic and the erotic: the politics of sexualities in contemporary India. Calcutta: Seagull.

Butler, Judith. 1990. Gender Trouble: Feminism and the Subversion of Identity. London: Routledge.

Caputo, John D. 2001. On Religion. London and New York: Routledge.

Carsten, Janet (ed). 2000. Cultures of Relatedness: New Approaches to the Study of Kinship (edited). Cambridge University Press.

Carsten, Janet. 2004. After Kinship. Cambridge University Press.

Chatterjee, Partha. 1993. The Nation and its Fragments. Princeton: Princeton University Press.

Cohen Laurence. 2005. The Kothi Wars: AIDS cosmopolitanism and the morality of classification. In Sex in Development: Science, Sexuality and Morality in Global Perspectives. V Adams and S Leigh Pigg, eds, pp 1-38. Durham, NC: Duke University Press.

Deshpande, Satish 2003. Contemporary India: a sociological view. New Delhi: Viking Penguin.

Devika, J. 2002. Domesticating Malayalees: Family planning, the nation and home-centred anxieties in Mid-20th century Keralam. Trivandrum, Kerala. CDS Working Paper No. 340, October 2002. Accessed online at http://ideas.repec.org/p/ind/cdswpp/340.html

Devika, J. 2005. The Malayalee Sexual Revolution: Sex, Family Planning and Gender in Keralam. Contributions to Indian Sociology 33(3): 
Devika, J. 2006. En-Gendering Individuals: The Language of Re-forming in Early 20th Century Keralam. Hyderabad, Orient Longman.

Devika, J. 2009. Bodies Gone Awry: The Abjection of Sexuality in Development Discourse in Contemporary Kerala. Indian Journal of Gender Studies February 2009 vol. 16 no. 1 21-46.

Dinshaw, Crolyn, Lee Edelman, Roderick A Ferguson, Carla Freccero, Elizabeth Freeman, Judith Halberstam, Annamarie Jagose, Christopher Nealon, Nguyen Tan Hoang. 2007. Theorizing Queer Temporalities: A Roundtable Discussion. GLQ 13,2-3: 177-196.

Donner, H. 2002. 'One's Own Marriage': Love Marriages in a Calcutta Neighbourhood. South Asia Research 22:79-94.

Dwyer, Rachel. 2000. All you want is money, all you need is love: sexuality and romance in modern India. London: Cassell/New York: Continuum.

Eagleton, Terry. 2009. Trouble with Strangers: A Study of Ethics. Oxford: Wiley-Blackwell.

Edelman, L. 1998. The Future is Kid's Stuff: Queer Theory, Disidentification and the Death Drive. Narrative, Vol 6,1:18-30.

Edelman, Lee. 2004. No Future: Queer Theory and the Death Drive. Durham, NC: Duke.

Fernandes, Leela. 2000. 'Nationalizing 'the Global': Media Images, Economic Reform and the Middle Class in India. Media, Culture and Society Vol 22, 5 (September): 611-628.

Foucault, Michel 1990 The History of Sexuality vol 1: An Introduction (The Will to Know). London: Penguin.

Franklin, Sarah and Susan McKinnon. 2001. (eds). Relative Values: Reconfiguring Kinship Studies. Durham: Duke University Press.

Freeman, Elizabeth. 2002. The Wedding Complex: Forms of Belonging in Modern American Culture. Duke University Press.

Freeman, Elizabeth. 2010. Time Binds: Queer Temporalities, Queer Histories. Duke University Press.

Fuller, Christopher. 1976. The Nayars Today. Cambridge: CUP.

Fuller, C. J. and H. Narasimhan. 2008. Companionate Marriage in India: the changing marriage system in a middle-class Brahman subcaste. JRAI 14,4:736-754.

Gardner, Andrew. 2011. Gulf Migration and the Family. Journal of Arabian Studies 1.1: 3-25.

Giddens, Anthony . 1992. The Transformation of Intimacy. Sexuality, Love and Eroticism in 
Modern Societies. Stanford: Stanford UP.

Gopinath, Gayatri. 2005. Impossible Desires: Queer Diasporas and South Asian Public Cultures. Duke University Press: Durham.

Grover, S. 2009. "Lived Experiences: Marriage, Notions of Love, and Kinship Support amongst Poor Women in Delhi". Contributions to Indian Sociology, 43 (1): 1-33.

Grover S. 2011a. 'Purani aur nai shaadi:' Separation, Divorce, and Remarriage in the Lives of the Urban Poor in New Delhi. AJWS Vol. 17 No. 1: 67-99.

Grover Shalini 2011 b. Marriage, Love, Caste And Kinship Support: Lived Experiences Of The Urban Poor In India. Delhi: Orient BlackSwan.

Halasa, Malu \& Rana Salam. 2008. The Secret Life of Syrian Lingerie: Intimacy and Design. San Francisco: Chronicle Books.

Halberstam Judith. 2005. In a Queer Time and Place: Transgender Bodies, Subcultural Lives. New York: NYU Press.

Hirschkind, Charles. 2006. The Ethical Soundscape: Cassette Sermons and Islamic Counterpublics. New York: Columbia University Press.

Howard, IKA. 1975. Mut'a marriage reconsidered in the context of the formal procedures for Islamic marriage. Journal of Semitic Studies XX(1):82-92.

Jackson, Peter A. 2009. Capitalism and Global Queering: national markets, parallels among sexual Cultures, and multiple Queer modernities. GLQ 15,3:358-395.

Jeffery, P., R. Jeffery and C. Jeffrey. 2004. Islamisation, Gentrification and Domestication: 'A Girls' Islamic Course' and rural Muslims in western Uttar Pradesh. Modern Asian Studies, 38, 1: $1-54$.

Jeffrey, Robin. 1976. The Decline of Nayar Dominance: Society and Politics in Travancore, 1847-1908. London, Chatto \& Windus for Sussex University Press.

Jeffrey, Robin. 1993. Politics, Women and Wellbeing: How Kerala Became "a Model". New Delhi: Oxford University Press.

John, Mary E and Janaki Nair. 1998. A question of silence? : the sexual economies of modern India. London, New York : Zed Books

Joseph, S. 2005. Learning Desire: Relational Pedagogies and the Desiring Female Subject in Lebanon. Journal of Middle East Women's Studies, Volume 1, Number 1, Winter 2005: 79-109. 
Karassery MN 1993. Unpublished PhD thesis on Literary and Cultural Value of Mapilla Songs. University of Calicut, Kerala.

Khanna, Akshay. 2007. 'Us Sexuality Types', in eds. The phobic and the erotic : the politics of sexualities in contemporary India / ed. by Brinda Bose and Subhabrata Bhattacharyya. - London / Delhi.

Khanna, A. 2009. Taming of the Shrewd Meyeli Chhele: A political economy of developments sexual subject. Development, Vol. 52, No. 1., pp. 43-51.

Kipnis, Laura. 2003. Against Love: A Polemic. New York: Pantheon.

Kodoth, P. 2001. Courting Legitimacy or Delegitimising Custom? Sexuality, Sambandham and Marriage Reform in Late-Nineteenth Century Malabar. Modern Asian Studies 35, no. 2: 2001.

Koya SM. 1983. Mappilas of Malabar: studies in social and cultural history. Calicut: Sandhya Publications.

Langford Wendy. 1999. Revolutions of the Heart: Gender, Power and the Delusions of Love.

McCaughey, M. \& C. French. 2001. Women's Sex-Toy Parties: Technology, Orgasm, And Commodification . Sexuality \& Culture, Volume 5, Number 3, 1 June 2001: 77-96.

Mahmood, S. 2001. Feminist Theory, Embodiment, and the Docile Agent: Some Reflections on the Egyptian Islamic Revival. Cultural Anthropology Volume 16, Issue 2: 202-236

Mahmood, Saba. 2005 Politics of Piety: The Islamic Revival and the Feminist Subject. Princeton and Oxford: Princeton University Press.

Mankekar, Purnima. 1999. Screening Culture, Viewing Politics: An Ethnography of Television, Womanhood, and Nation in Postcolonial India. Durham and London: Duke University Press.

Mazzarella, William. 2001. 'Citizens Have Sex, Consumers Make Love': Marketing KamaSutra Condoms in Bombay. In B. Moeran, ed., Asian Media Productions. University of Hawai'i Press.

Merchant, Hoshang. 1999. Yaraana: Gay Writing from India. New Delhi: Penguin Books.

Metcalf, Barbara D. 1984. (ed.). Moral Conduct and Authority; The Place of Adab in South Asian Islam. Berkeley: University of California Press.

Osella, Caroline \& Filippo Osella. 2006 Men and Masculinities in South India. Anthem Press: London.

Osella, C. \& F. Osella. 2007. Muslim Style in South India. Fashion Theory: The Journal of Dress Body \& Culture 11, nos. 2-3: 233-252. 
Osella, Caroline \& Filippo Osella. 2008a 'Nuancing the migrant experience: perspectives from Kerala, South India.' In: Koshy, S. and Radhakrishnan, R., (eds.), Transnational South Asians: the making of a neo-diaspora. India: Oxford University Press:146-178.

Osella, C. \& F. Osella. 2008b. Food, Memory, Community: Kerala as both 'Indian Ocean' Zone and as Agricultural Homeland. South Asia Journal of South Asian Studies, 31 (1). pp. 170-198.

Osella, Filippo. In Press. Due 2012. 'Men's sociality Across the Indian Ocean', in special issue entitled 'Queer Asian Subjects', eds Evie Blackwood and Mark Johnson, Asian Studies Review, Vol 36, no. 2.

Osella, Filippo \& Caroline Osella. 2000 Social Mobility in Kerala: Modernity and Identity in Conflict. Pluto, London \& Sterling (Virginia).

Osella, Filippo and Caroline Osella. 2007. "I am Gulf!": the production of cosmopolitanism in Calicut, Kerala", in Struggling with History - Cosmopolitanism contested: The confluence of history and anthropology in the Indian Ocean, eds. Edward Simpson, Kai Kresse, 323-355. London: Hurst:

Osella, F. \& C. Osella. 2008a Introduction: Islamic reformism in South Asia.' Modern Asian Studies, 42 (2/3): 247-257.

Osella, F. \& C. Osella. 2008b 'Islamism and Social Reform in Kerala, South India.' Modern Asian Studies, 42 (2-3): 317-346.

Otnes, Cele C. and Elizabeth H. Pleck. 2003. Cinderella Dreams: The Allure of the Lavish Wedding. Berkeley: University of California Press.

Parkin, D. 1989. Swahili Mijikenda: facing both ways in Kenya. Africa 59,2:161-175.

Parry Jonathan. 2004. The marital history of a "thumb impression man." In Telling lives: South Asian life histories, D. Arnold and S. Blackburn (eds). New Delhi/Bloomington: Permanent Black/Indiana University Press.

Patel G. 2004. Homely Housewives Run Amok: Lesbians in Marital Fixes. Public Culture 16.1 (2004) 131-157

Patel G. 2006. Risky subjects. Social Text 89, Vol 24,4: 5 -62.

Peletz, Michael. 2001. Ambivalence in Kinship Since the 1940s. In Relative Values:

Reconfiguring Kinship Studies. Sarah Franklin and Susan McKinnon, eds. Pp. 413-443. Durham: Duke University Press.

Pernau, Margrit. 2003. Motherhood and female identity: Religious advice literature for women in German Catholicism and Indian Islam. In M. Pernau, I. Ahmad, \& H. Reifeld (Eds.), Family and gender: Changing values in Germany and India (pp. 140-161). New Delhi: Sage. 
Phadke, Shilpa, Sameera Khan \& Shilpa Ranade. 2011. Why Loiter?: Women and Risk on Mumbai Streets. New Delhi: Penguin Books.

Povinelli E.A. 2002. Notes on Gridlock: Generalogy, Intimacy, Sexuality. Public Culture 14(1): 215-238.

Povinelli E.A. 2011. Beyond Good and Evil: Whither Liberal Sacrificial love? Public Culture $21: 1: 77-100$.

Ring, Laura A. 2006. Zenana: Everyday Peace in a Karachi Apartment Building Bloomington, IN: Indiana University Press.

Rubin, Gayle. 1975. The Traffic in Women: Notes on the 'Political Economy' of Sex, in Rayna Reiter, ed., Toward an Anthropology of Women, New York, Monthly Review Press.

Sedgwick, Eve Kosofsky. 1990. 'Axiomatic', Introduction to her Epistemology of the Closet. Berkeley: Univ. California Press.

Simpson Edward and Kai Kresse. 2007. Struggling with History: Islam and Cosmopolitanism in the Western Indian Ocean. London: Hurst.

Simpson, Bob. 1994. "Bringing the 'Unclear' Family Into Focus: Divorce and Re-Marriage in Contemporary Britain". Man (Royal Anthropological Institute of Great Britain and Ireland) 29 (4): 831-851

Simpson, Bob. 1998. Changing Families: an ethnographic approach to divorce and separation. Oxford: Berg.

Srivastava, Sanjay. 2004. Sexual Sites, Seminal Attitudes: Sexualities, Masculinities and Culture in South Asia. New Delhi, London, and Newbury Park: Sage.

Srivastava, Sanjay. 2007 Passionate Modernity. Sexuality, Gender, Consumption, and Class in South Asia. London, New York: Routledge .

Strathern, M. 1996. Cutting the Network. JRAI Vol. 2, No. 3 (Sep., 1996), pp. 517- 535

Strathern, Marilyn. 1992. After Nature: English Kinship in the Late Twentieth Century. Cambridge: Cambridge University Press.

Strathern, Marilyn. 2005. Kinship, law and the unexpected: Relatives are often a surprise. Cambridge: Cambridge University Press.

Strathern 2008. Missing Men, in American Ethnologist 32,1: 28-29.

Stivens, Maila 1996. Matriliny and Modernity: Sexual politics and social change in rural Malaysia. NSW: Allen and Unwin. 
Sutton, Tyler H. 2007. The Emergence of a Male Global Gay Identity: A Contentious and Contemporary Movement. In Totem: The University of Western Ontario Journal of Anthropology. Volume 15, Issue 1: 50-58.

Thapan, Meenakshi. 2009. Living the Body: Embodiment, Womanhood and Identity in Contemporary India. New Delhi: Sage.

Uberoi, Patricia . 2006. Freedom and Destiny: Gender, Family, and Popular Culture in India. Delhi: Oxford University Press.

Van Wessel, M. 2004. 'Talking about Consumption: How an Indian Middle-Class Dissociates from Middle-class Life'. Cultural Dynamics 16, 1, 93-116.

Wadley, Susan S. 2010 One Straw from a Broom Cannot Sweep: The Ideology and Practice of the Joint Family in Rural North India. In Everyday Life in South Asia. Diane P. Mines and Sarah Lamb eds. Pp. 14-25. Bloomington: Indiana University Press.

Warner Michael. 2000. The Trouble with Normal: Sex, Politics and the ethics of queer life. Cambridge: Harvard University Press.

Welchman, Lynn. 2010. Bahrain, Qatar, UAE: First time Family Law Codifictions in Three Gulf States. International Survey of Family Law, (ed) Bill Atkin: 163-178. Bristol: Jordan.

Zachariah, K.C., E.T. Mathew, and S. Irudaya Rajan. 2003. Dynamics of Migration in Kerala: Dimensions, Determinants and Consequences. Hyderabad: Orient Longman.

\section{Online Sources}

Times of India, 26.6.2010. Kerala CM reignites 'love jihad' theory. Accessed 09.08.11 at: http://articles.timesofindia.indiatimes.com/2010-07-26/india/28290879 1 pfi-muslim-womenlove-and-money. Accessed 01.03.12

'Gender and Love' project at: http://www.inter-disciplinary.net/critical-issues/gender-andsexuality/gender-and-love/ Accessed 01.03.12.

'Thekkepuram web Forum" at http://pub25.bravenet.com/forum/static/show.php?usernum $=2082489322 \&$ frmid $=381 \& \mathrm{msgid}=2$ 989\&cmd=show 
Hit Mappila pathu (Kerala Muslim song) Song 'palnila punchiri', at http://www.youtube.com/watch?v=WEAZkr-M6yU. Accessed 01.03.12.

\section{Notes}

${ }^{1}$ I have no space to engage with Povinelli's recent critical discussion of sacrifice (2011) except to counter her ambivalence with Terry Eagleton (2009) and John Caputo (2001) on the productive possibilities for (recuperated) Christian ethics, and to promise to write a future paper myself on the usefulness of concepts such as sacrifice, radical hospitality and abundant love.

2 'Gender and Love' project at: http://www.inter-disciplinary.net/critical-issues/gender-andsexuality/gender-and-love/

3 Queer writers have explored the degree to which linear time, normative life-cycle and heteronormativity are tied up together, and the place of reproduction and parenting in producing 'straight time' (Edelman 1998, 2004; Halberstam 2005; Patel 2006; Dinshaw et al 2007; Freeman 2010).

${ }^{4}$ cf. Otnes \& Pleck 2003 on how desire is often actually directed towards the 'wedding' itself and see also Freeman 2002 on the queer desires hidden / displaced in the very fabric of the wedding.

5 While the official name is now Kozhikode, I follow usage of most Koya Muslims, who continue to use the old colonial name of Calicut for the town.

${ }^{6}$ On Kerala Muslim use of 'mut'a 'marriage see SM Koya 1983: $12 \mathrm{ff}$. Scholars of Islam will be interested and possibly surprised to find the common use here of the term 'mut'a' for these long-term liaisons; a term which belongs properly to Shia Islam, not to Sunni (Howard 1975), which Kerala's Islam is; being also a technically incorrect usage of the term in any case (since no termination date was fixed; cf. Sunni misyar, no cohabitation expected (Welchman 2010).

${ }^{7}$ Cf. Devika's noting that post 1960s productions of/discussions of sexual desire as a 'bodily need' cannot imagine female sexual autonomy, but only 'married love', as solution to the perceived need $(2005,2009)$.

${ }^{8}$ An outfit with tight blouse and flimsy veil, worn at the pre-wedding women-only gathering and not considered decent for wear in mixed-sex company.

${ }^{9}$ To see an example of a studio produced commercial DVD of glamourized and idealized oppana and Mapilla pathu for Kerala Muslim consumption, see the super-hit song Palnila Punchiri by Midad. http://www.youtube.com/watch?v=WEAZkr-M6yU. Accessed 01.03.12.

10 See online discussions in English among (mostly non resident) Koyas on the topic of 'marriage' archived in the Thekkepuram web forum (Thekkepuram being the name for the zone of Calicut which is where Koyas have mostly had residence). At

http://pub25.bravenet.com/forum/static/show.php?usernum=2082489322\&frmid=381\&msgid=2989\&cmd= show 
11 'Boyfriend' here is an innocent relationship consisting mostly of glances, perhaps written letters, and conversation. 